\title{
STRATEGY OF AVIAN INFLUENZA VACCINE DEVELOPMENT AS A STEP TO CONTROL
}

\author{
Syamsidar ${ }^{* 1}$, Jono M Munandar**), Eko Ruddy Cahyadi**), and Aprilia Kusumastuti*) \\ *) Study Program of Management Science, Postgraduate School, Bogor Agricultural University \\ Jl. Agatis IPB Darmaga Campus, Bogor 16680 \\ ${ }^{* *}$ Department of Management, Faculty of Economics and Management, Bogor Agricultural University \\ Jl. Agatis IPB Darmaga Campus, Bogor 16680
}

\begin{abstract}
Avian Influenza Disease (AI) is a disease that can cause high mortality up to $100 \%$ in laying hens so it is very harmful. One of the strategic steps of AI disease control and prevention is vaccination by inducing immunity before infection with avian influenza disease. AI vaccine development strategy is needed to increase the company's market share of the organization. The purpose of this research is to analyze the development strategy of AI vaccine according to the requirement of laying chicken breeder in West Java. Data analysis uses quality function deployment (QFD). The result of the research indicates that the consumer's priority of absolute weight is the composition $(5,51)$, laboratory service $(3,78)$, certification $(3,42)$ and price $(3,33)$. Technical requirements as a step to translate customer requirements into technical steps to achieve a match between AI vaccines developed with consumer desires from absolute weight values is to make coctail compositions 89 , set competitive prices (75), to vary the packaging volume (64) ) and from the relative weight value of making the coctail composition 88, setting the competing price (65), making the product innovation a viral content update based on disease progression in the field (56), making the smaller dosage pack volume (55). Managerial implications based on research results which is recommended to manufacturers to meet consumer needs is to focus on development, improvement, planning and control to the priority of the variables that are concerned with designing AI vaccine products.
\end{abstract}

Keywords: avian influenza, laying hens, strategies of improving, vaccine AI, quality function deployment

\begin{abstract}
Abstrak: Penyakit Avian Influenza (AI) merupakan penyakit yang mampu menimbulkan kematian tinggi hingga $100 \%$ pada ayam petelur sehingga sangat merugikan. Salah satu langkah strategis pengendalian dan pencegahan penyakit AI adalah vaksinasi dengan menginduksi kekebalan sebelum terinfeksi dengan penyakit avian influenza. Srategi pengembangan vaksin AI diperlukan untuk peningkatan market share perusahaan organisasi. Tujuan dari penelitian ini adalah untuk menganalisis strategi pengembangan vaksin AI sesuai kebutuhan peternak ayam petelur di Jawa Barat. Analisis data menggunakan quality function deployment (QFD). Hasil penelitian menunjukkan persyaratan konsumen yang diperioritaskan dari nilai bobot absolut adalah komposisi $(5,51)$, layanan laboratorium $(3,78)$, sertifikasi $(3,42)$ dan harga $(3,33)$. Persyaratan teknik sebagai langkah untuk menerjemahkan persyaratan konsumen kedalam langkah-langkah teknis agar dapat tercapai kesesuaian antara vaksin AI yang dikembangkan dengan keinginan konsumen dari nilai bobot absolut adalah membuat komposisi coctail (89), menetapkan harga bersaing (75), membuat variasi volume kemasan (64) dan dari nilai bobot relatif yaitu membuat komposisi coctail (88), menetapkan harga bersaing (65), membuat inovasi produk berupa update kandungan virus berdasarkan perkembangan penyakit dilapangan (56), membuat volume kemasan dosis yang lebih kecil (55). Implikasi manajerial berdasarkan hasil penelitian yang direkomendasikan pada produsen untuk memenuhi kebutuhan konsumen adalah dengan memfokuskan pada pengembangan, perbaikan, perencanaan dan kontroling terhadap prioritas variabel yang dipentingkan dalam mendesain produk vaksin AI.
\end{abstract}

Kata kunci: avian influenza, ayam petelur, strategi pengembangan, vaksin AI, quality function deployment

${ }^{1}$ Corresponding author:

Email: syamsidar23@ymail.com 


\section{INTRODUCTION}

Indonesia is one of the countries that has endemic with Avian influenza disease (Songserm et al. 2006; Smith, 2006) since 2003 the disease is widespread. Two years after the outbreak of AI, the government announced through the Decree of Minister of Agriculture Number 96/Kpts/ PD.620/ 2/2004 that AI has spread in 23 Provinces, 151 Regencies or Municipalities with the mortality rate around 10.45 million chickens (Basuno 2008). AI causes a considerable death of 6.2 million chickens (Putri, 2012). AI is categorized as Zoonotic (can be transmitted to humans) and have killed people.

The data from WHO in December 2013 indicates that the total cases in humans as many as 195 cases and caused died as many as 163 people (Wong et al. 2008;WHO, 2013). It is reported in 2006 as many as 241 cases of infection with 141 died (Radji, 2006). In 2015 there are 197 cases in human and confirmed it is infected by AI virus (H5N1) in Indonesia, 165 of them are fatal (Secretary General of Ministry of Health, 2015). Live poultry market surveillance indicates that AI virus is still circulating in poultry farms in Indonesia and tends to increase at the beginning of the year in the season change (Zenal, 2017) (Figure 1). AI circulating in poultry farms in 2016 can cause deaths of 107,571 birds or 26\% (Azhar, 2016).

Laying hens in Indonesia are still dominated by traditional (extensive) and semi-intensive maintenance systems with open house systems that are vulnerable to disease (North, 1984; Tabbu, 2000). According to Ilham (2013), the pattern of maintenance of units that is still largely extensive and semi-intensive has a high chance of transmitting diseases between ducks and wild birds in the field. Ratnawati et al. (2010) also stated that in increasing chicken productivity the pattern of maintenance has developed in semi intensive and intensive systems although the extensive pattern of tradition is still dominant. Modern chicken farming (intensive) is only applied by a small number of farmers, in an intensive maintenance pattern if there is an error in the implementation of maintenance management will impact economic losses, especially infectious diseases such as one of them is AI. Model maintenance and density of chicken populations often become obstacles in Diyantoro and Pribadi (2017).
In response to AI outbreak case, Ministry of Agriculture of Republic Indonesia establishes the strategic steps in controlling, disseminating and eradicating of AI through Directorate of Animal Health. The stipulation is stated in Decree number $17 / \mathrm{kpts} / \mathrm{PD} / 640 / \mathrm{F} / 02.04$ on the establishment of nine strategic steps of $\mathrm{AI}$ controlling. One of the strategies is vaccination. Sudarisman (2006); Suwito et al. (2013) also state that the controlling and eradicating of AI in Indonesia has included the extensive vaccination program. AI vaccination is the provision of antigen in chickens to stimulate the immune system to produce AI-specific antibody to make the chickens become immune to AI.

AI vaccination in poultry is growing very rapidly in line with the development of chicken industry. An intensive poultry farming model with a capacity of hundreds to thousands of poultries leads to vaccine needs in large numbers (Parede, 2016). AI Vaccination in laying hens is conducted 5 times in one cycle of maintenance period as recommended by FAO, it is conducted 3 times before entering the period of egg laying and 2 times after entering the period of egg laying. IN addition, the strict $\mathrm{FAO}$ vaccination program describes the number of vaccines needed by Indonesia in AI preventing and handling is huge. The survey data of farms by Indonesia Statistics in 2017 indicates that the population of laying hens in Indonesia in 2016 on average is 162,051,262 chickens per year. The need for AI vaccine in Indonesia (if it is assumed $90 \%$ chickens are vaccinated) based on the population data of laying hens is $729,230,679$ dose/year.

The circulation of AI vaccine in Indonesia is limited by the government and has been regulated in the Regulation of Minister of Agriculture. The use of diverse AI vaccine in farms is feared to increase the potential for genetic mutations and making it more difficult to cope with. This risk results in AI vaccine import from outside the country and it prohibited to enter Indonesia according to Circular Letter of Minister of Agriculture number 3345, July 13, 2011 that states AI vaccine other than the determined by government (local vaccine) should be withdrawn from the circulation. The only available AI vaccine allowed from local registered vaccine producers in Indonesia, namely PUSVETMA, PT Vaksindo Satwa Nusantara, PT Medion, PT Caprifarmindo, PT Sanbio Laboratories and PT IPB Shigeta Animal Pharmaceuticals (IPB Shigeta). 


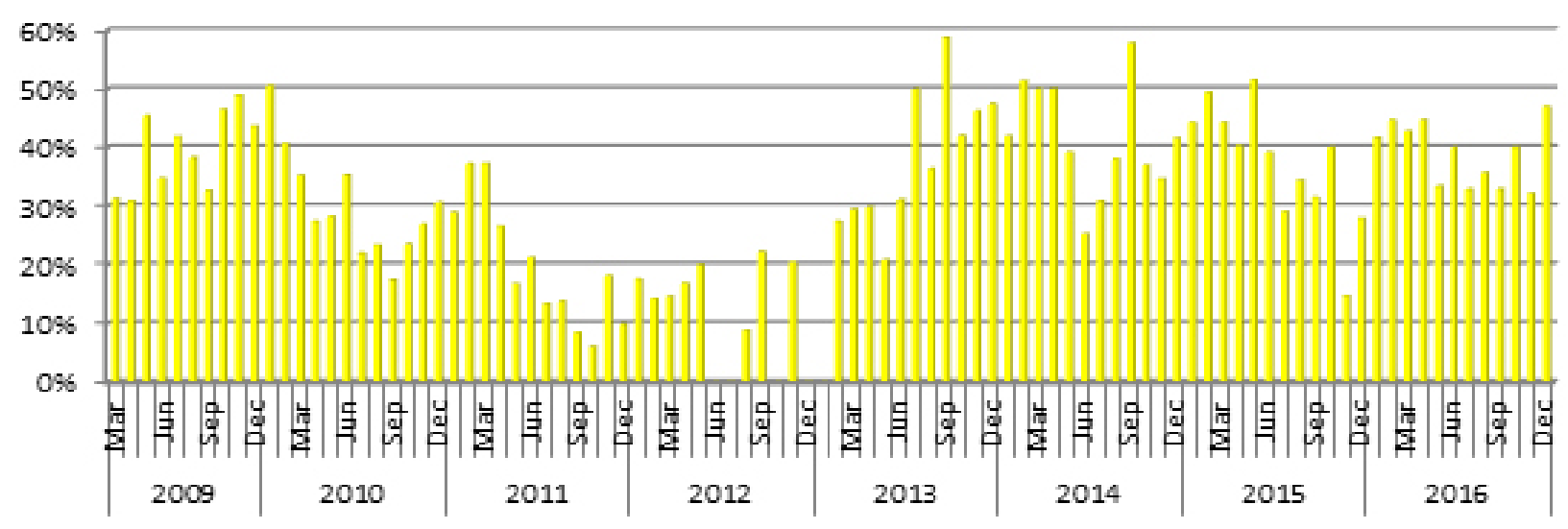

Figure 1. Percentage of live poultry market indicating AI positive result

PTABC as one of vaccine manufacturers is the registered vaccine manufacturers in Indonesia and continues to expand to develop AI vaccine market. High demand and restriction of $\mathrm{AI}$ vaccine products coming into Indonesia is a great opportunity for $\mathrm{PT} \mathrm{ABC}$ as vaccine producer, although the market share competition among AI vaccine manufacturers in Indonesia is quite strict. The data compiled by comparing the population of laying hens in 2015-2016 with the sale of AI vaccine products manufacturer by $\mathrm{PT} A B C$ can be seen that $\mathrm{PT}$ $\mathrm{ABC}$ only controls the market share of $10.65 \%$. The data indicates that PT ABC is still in the lowest position in mastering market share compared to its competitors. This illustrates that PT.ABC still need to make product development strategy design so that the product can be accepted by consumer to Increase Company's success and market share.

This research only focuses on AI vaccine product about AI vaccine development strategy; this research was conducted on laying hens farm in West Java area in Bogor and Sukabumi area

\section{METHODS}

This study was conducted in West Java Province because it was the province with the highest population density of livestock in Indonesia with 15,830,703 in 2016 but had the highest AI case rate in Indonesia reported by Department of Agriculture in 2015 as many as 35 cases and in 2016 as many as 75 cases (Figure 2). The research was focused on Bogor and Sukabumi areas because it was the center of livestock with laying population of $57 \%$ of the total population in West Java.
The data used in this study was primary data taken from the survey with breeders who used AI vaccine with the help of structured questionnaire. The interview with the vaccine industry was also conducted to obtain a comprehensive data. Secondary data was obtained from literature sources that were supporting this research. Secondary data collection came from literature studies, books, web, articles, livestock seminars, researchrelated laws, Indonesian Statistic (BPS) data that could provide research-related information. Secondary data collected in the form of population of laying hens in West Java, number of AI incidence, rules related to AI and its prevention.

The population in this study was the whole chicken breeders who bought and used AI vaccine in West Java which is focused on Bogor and Sukabumi area. The census of Indonesian Statistics data in 2013 indicated that number of laying chicken breeders in Bogor as many as 171 people and Sukabumi as many as 74 people (BPS, 2017). The determination of sample amount was using Slovin formula (error of 10\%) so that it obtained 71 samples. The withdrawal of the sample number was conducted proportionally that was Bogor area as many as 50 samples and Sukabumi as many as 21 samples. The sample of farmers taken from independent breeders was small, medium and large scale with the provisions of farmers using AI vaccine.

Analyze technique was using Quality Function Deployment (QFD) method to make AI vaccine development strategy. QFD method was a structured methodology used in the process of planning and product development to determine the specification of consumer needs and expectation, thus it systematically evaluated the capability of a product or service in met the consumer needs and expectation. Purpose of this 
method used in AI vaccine development strategy at PT. $\mathrm{ABC}$ was to translating consumer needs in technical characteristic and specification, as well as built and delivered quality products by focusing on customer satisfaction.

Stages of QFD method using House of Quality matrix (HoQ) were as follows:

1. Set consumer requirements (What). Identified consumer's needs and expectation on AI vaccine by "what". This determination was conducted by exploring deeper into the Voice of Custemer (VOC) to establish the expected essential attributes for AI vaccine products. The VOC determination was performed by interviewing the consumers related to what consumers need on AI vaccine products about the quality, quantity, continuity and after-sales service offered

2. Set technical requirements (How). Technical requirements were taken from responses to the answers from consumer expectation matrix (what). The answers to these technical requirements were translated into consumer requirements technical measures toachieve a consistencybetweenAIvaccine developed by PT ABC and consumer expectation. Technical requirements were obtained from interview with AI vaccine industry by developing vaccine product design attributes includes product development according to customer needs that would affect consumer expectation. The interview was conducted to Manager and Staff of PT ABC in Research and Development, Production, and Quality Control section. The processed data would be incorporated into upper part of HoQ matrix.

3. Developed a matrix relationship between consumer

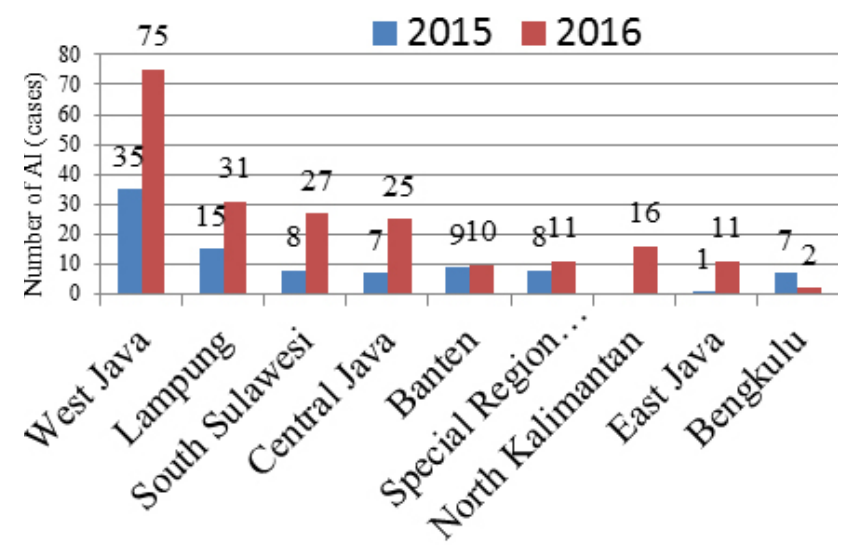

Figure 2. Distribution of AI in 2015 \& 2016 (Department of Agriculture, 2017) requirements and technical requirements determined by the effect degree graph of each of What and How matrix. The effect among the matrix was determined using symbol and value, the relationship or strong effect $(\Theta=9)$, medium $(\mathrm{O}=3)$, weak $(\boldsymbol{\Delta}=1)$, and no effect $(\square=0)$

4. Developed a relationship matrix amongst the technical requirements to identify strong or mutually supportive relationship with weak or conflicting relationship among technical requirements described by symbols and values. The symbol ++ strong positive relationship with the value of $(+10)$, symbol + weak negative relationship with the value of $(+5)$, symbol - strong negative relationship with the value of $(-10)$, no symbol relationship $\square$ value (0)

5. The competitive assessment of consumer requirements and technical requirements would describe competing AI vaccine products with the organization's vaccine product. The competitive assessment of consumer and the competitive assessment of technique were determined using likert scale $($ excellent $=5),($ good $=4),($ good enough $=3),($ not good $=2),($ very poor $=1)$.

6. Developed priority requirements of consumers by ranking based on the level of consumer interest that would be used in prioritizing the business and made trade off decision. The priority of these consumer requirements consisted of a column of interest for the consumer, value of target, scale factor of increase, point of sale and the absolute weight.

7. Developed priority technical requirements to identify the most required technical requirements and prioritized customer requirements and required improvement. The technical requirements priority included degree of difficulty, target value, absolute weight, and relative weight.

AI disease is an endemic disease in Indonesia. This disease is very detrimental to relevant stakeholders such as poultry farmers. The losses incurred are in the economic field (outbreak AI), social (zoonosis), politics (government policy), and environment (the spread of the virus). Based on AI case data, West Java is the highest area of AI outbreak. This is related to the density of poultry traffic in West Java. One way to overcome AI disease is by vaccination. Nofifta (2015) mentioned that vaccination has a very important advantage to prevent AI disease.

The survey of AI vaccine used in farms in West Java 
showed that farmers changed the brands of AI vaccine they used very often. However, data from the Indonesian Animal Drug Index (IOHI) stated that the AI vaccine that available in Indonesia is not much different from one another. The AI vaccine in Indonesia generally contains AI H5N1 clade 2.1.3, AI H5N1 clade 2.3.2 or a combination of both. This is a question mark about what important factors in the selection and purchase of AI vaccine to prevent $\mathrm{AI}$ cases. If it is associated with the vaccine industry, what strategy should be undertaken to produce vaccines that match the wants and needs of the breeder. Data is analyzed to answer the questions by QFD method. Research framework in Figure 3.

\section{RESULTS}

AI vaccine market share is observed to see the size of the market controlled by AI vaccine manufacturers. Relative market share analysis indicates the size of company's market share of sales volume from AI vaccine products in West Java. This market share is taken from the observation of respondents who provide answers to the brand of used vaccine. The market share of this study indicates that PT. MDN has the highest market share (29\%), followed by PT. VSN (25\%) (Figure 4). PT ABC compared to its competitors which only have a low market share of $21 \%$ of the whole.

The low market dominance of PT ABC compared to its competitors due to $\mathrm{PT} A B C$ is a new vaccine production industry that operates 4 years in Indonesia. Assessment of market share continues to be performed by PT ABC while other companies have been operating for a long time so that the produced vaccine products are better known by consumers. This is a challenge for PT. ABC to continue to expand its market share, brand building, and vaccine quality to exceed its existing competitors.

This AI vaccine market share describes the company's position or measures the company's strength in the vaccine industry competition. Suprapti and Nuraeni (2009) stated that the higher the market share control reflects the higher company's strength in market competition.

The vaccine company's market share can be achieved through extensive vaccine distribution, high-quality and innovative products, as well as competitive pricing so that the purchasing power of farmers are high. The broad market share reflects the acceptance and demand of high vaccine products. This condition shows the high purchasing power of farmers at competitive prices affecting the vaccine company's market share.

Nurliza and Dolorosa (2017) stated that consumer still remains the determinant of the quality which is diversity at market. Consumers may focus on the specification quality of a product, or how it compares to competitors in the market place. AI vaccine product development strategy is analyzed using QFD method with House of Quality Matrix (HoQ) with stages.

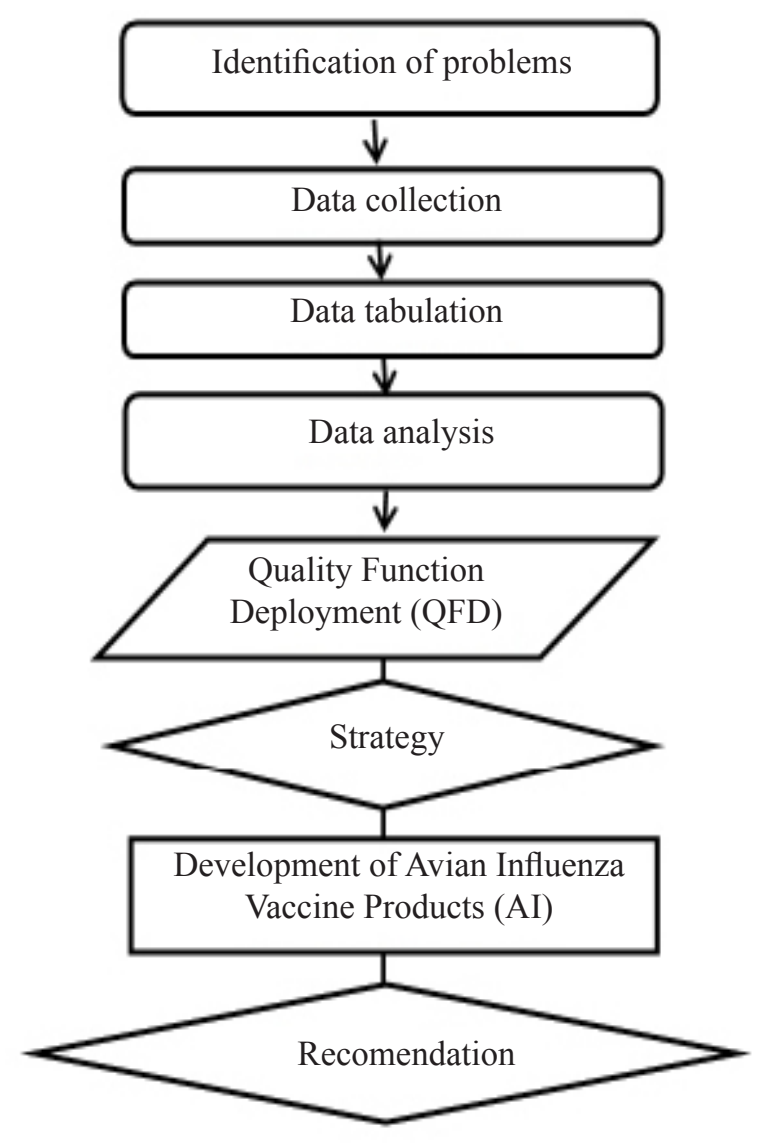

Figure 3. Research framework

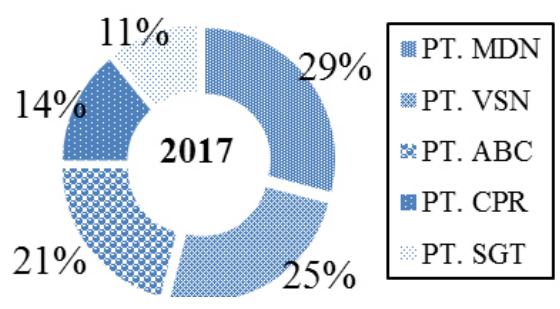

Figure 4. AI Vaccine market share in West Java 


\section{Preparation of customer requirements (what)}

Result of interview is in the form of extracting information related to the required attributes by consumers in buying and using AI vaccine in Table 1.

\section{Preparation of technical requirements (how)}

The set technical requirements from the interview with PT ABC are in the form of technical activities (processes) affecting the quality of products described in several indicators in Table 2.

\section{Development of relationship matrix between What and How}

The relationship among the customer requirements can have one or more relationships on the technical requirements, and vice versa. A strong relationship $(\Theta)$ occurs because the costumer requirement and technical requirement are mutually affecting each other. A weak relationship ( $\boldsymbol{\Delta})$ occurs because the customer requirement and technical requirement have low linkage. Customer requirement that is not related to technical requirement ( $\square$ ) indicates that each requirement does not affect each other. Relationship matrix development between What and How in Figure 5.

Table 1. Preparation of customer requirements

\begin{tabular}{|c|c|c|c|}
\hline Variable & Number & Indicator & Operational Concept \\
\hline Price (A) & $\begin{array}{l}1 \\
2 \\
3\end{array}$ & $\begin{array}{l}\text { Price } \\
\text { Payment Provision } \\
\text { Discount (payment period) }\end{array}$ & $\begin{array}{l}\text { Financial value placed on AI vaccine } \\
\text { Discount given when purchasing AI vaccine } \\
\text { Payment period after AI vaccine accepted by the consumer }\end{array}$ \\
\hline Quality (B) & $\begin{array}{l}4 \\
5 \\
6 \\
7\end{array}$ & $\begin{array}{l}\text { Composition } \\
\text { Varied packaging volume } \\
\text { Expired date } \\
\text { Packaging design } \\
\text { Dose }\end{array}$ & $\begin{array}{l}\text { The vaccine content that can protect from AI } \\
\text { AI vaccine products have a variety of small, medium, and large } \\
\text { packaging in ml unit } \\
\text { Period of AI vaccine can be used after production } \\
\text { The form of creative packaging, has its attraction and able to } \\
\text { protect the product } \\
\text { Amount of vaccine injected in the chickens in ml unit }\end{array}$ \\
\hline $\begin{array}{l}\text { After Sale } \\
\text { Service }(C)\end{array}$ & $\begin{array}{c}9 \\
10\end{array}$ & $\begin{array}{l}\text { Vaccinator service } \\
\text { Laboratory services }\end{array}$ & $\begin{array}{l}\text { Vaccine service provided by AI vaccine manufacturer } \\
\text { Provided laboratory service is in the form of } \mathrm{HI} \text { and PCR test, and } \\
\text { sequencing of AI vaccine manufacturers }\end{array}$ \\
\hline $\begin{array}{l}\text { Company } \\
\text { Reputation } \\
\text { (D) }\end{array}$ & 11 & $\begin{array}{l}\text { Has national and } \\
\text { international certification }\end{array}$ & $\begin{array}{l}\text { The AI vaccine manufacturer has a certification number as a } \\
\text { guarantee that the product meets certain required standard }\end{array}$ \\
\hline
\end{tabular}

Table 2. Preparation of technical requirements

\begin{tabular}{cl}
\hline Number & Indicator \\
\hline 1 & Creating product innovation in the form of virus content update based on disease progression in the field \\
2 & Create vaccine volume variation (ml/bottle) \\
3 & Development of model and product packaging design \\
4 & Make discount strategy to increase sales \\
5 & The grace period is a maximum of 3 months \\
6 & Provision/Improvement of vaccinator service \\
7 & Provision/laboratory service improvement in vaccination monitoring and disease handling \\
8 & Ensure the quality of vaccine by the national and international certification \\
9 & Make the smaller dose of volume \\
10 & Make the composition of cocktail \\
11 & Set a competitive price (competitive)
\end{tabular}




\section{Development of relationship matrix amongst the technical requirements (how)}

The relationship matrix among the technical requirements aims to identify any technical requirements that are mutually supporting and conflicting one another. The relationship is in the form of a strong positive relationship (++) indicating a unidirectional relationship. If one of the process characteristics increased, it will have a strong impact on other characteristics. A weak positive relationship (+) indicates a unidirectional relationship but the resulting impact is not quite strong. A weak negative relationship (-) indicates a conflicting relationship but the resulting impact is little. A strong negative relationship (--) does not occur among the technical requirements. In case there much strong and weak negative relationship among the technical requirements and there will be trade-off that makes it difficult for the organization to develop and improve. Development of relationship matrix amongst the technical requirements in Figure 6.

\section{Competitive assessment}

Customer competitive assessment aims to determine met consumer requirements and identify consumer requirements that need to be evaluated and developed/ improved to match even exceeding its nearest competitor. Consumer requirements such as price, discount, payment provision, vaccinator service, and laboratory service at PT ABC have high value compared to some of its competitors. Consumer requirements such as quality, packaging design, dosage, and certification at PT ABC have the same value with all its competitors. Nevertheless, customer requirements should be continuously evaluated and developed to survive and compete with its competitors.

Vaccine customers demand more complete and detailed attributes, such as attributes not limited to quantity and price, but also aspects of product safety attributes, nutritional attributes, value attributes, packet attributes, ecolabel attributes, product traceability attributes and humanistic attributes. Consumer competitive assessment in Figure 7.

\begin{tabular}{|c|c|c|c|c|c|c|c|c|c|c|c|}
\hline $\begin{array}{c}\text { How } \\
\text { What }\end{array}$ & 1 & 2 & 3 & 4 & 5 & 6 & 7 & 8 & 9 & 10 & 11 \\
\hline 1 & $\boldsymbol{\Delta}$ & & & $\mathrm{O}$ & $\mathbf{\Delta}$ & & & & & $\Theta$ & $\Theta$ \\
\hline 2 & & & & $\Theta$ & & & & & & & $\mathrm{O}$ \\
\hline 3 & & & & $\boldsymbol{\Delta}$ & $\Theta$ & & & & & & $\boldsymbol{\Delta}$ \\
\hline 4 & $\Theta$ & & & & & & & & $\mathrm{O}$ & $\Theta$ & $\boldsymbol{\Delta}$ \\
\hline 5 & & $\Theta$ & & & & & & & $\mathrm{O}$ & & $\mathrm{O}$ \\
\hline 6 & & & & $\mathrm{O}$ & & & & & & & \\
\hline 7 & & $\Theta$ & $\Theta$ & & & & & & $\mathrm{O}$ & & $\mathbf{\Delta}$ \\
\hline 8 & $\boldsymbol{\Delta}$ & $\mathrm{O}$ & $\mathbf{\Delta}$ & & & & & & $\Theta$ & $\mathrm{O}$ & $\mathrm{O}$ \\
\hline 9 & & & & & & $\Theta$ & & & & & \\
\hline 10 & & & & & & & $\Theta$ & & & & \\
\hline 11 & & & & & & & & $\Theta$ & & & \\
\hline
\end{tabular}

Figure 5. Relationship matrix development between What and How (sequence number 1-11 is variable of consumer requirements (what) $\&$ technical requirements (how)).

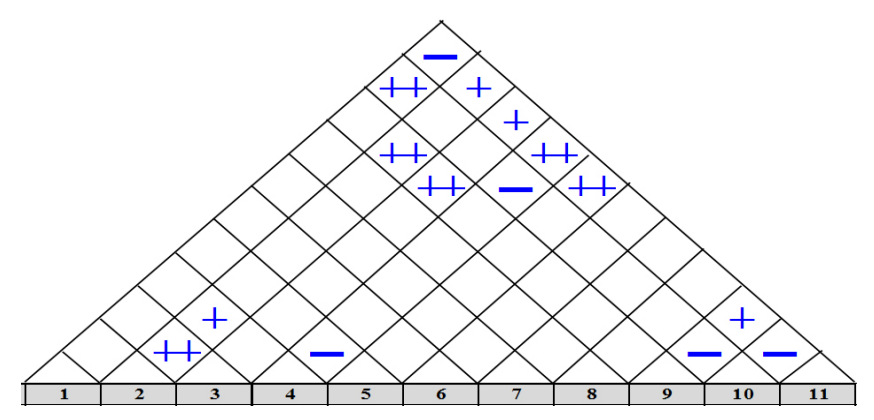

Figure 6. Development of relationship matrix amongst the technical requirements (sequence no 1-11 is a technical requirement variable).

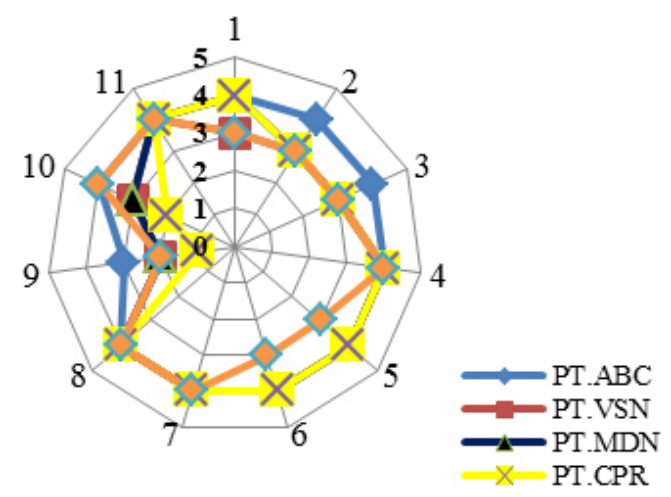

Figure 7. Consumer competitive assessment (sequence number $1-11$ is variable of consumer requirement). 
The technique competitive assessment aims to compare the performance of organization's technical requirements with its competitors. Assessment that has the same value with its competitors needs to be maintained but a lower valuation needs to be improved to match or exceed its competitors. Technical requirements that have advantages over several competitors are making product innovation in the form of virus content updates based on disease progression in the field, the provision/ improvement of laboratory service in vaccination monitoring and disease handling and making cocktail composition. Technical Competitive Assessment in Figure 8.

In the competition, the ability of companies to meet consumer needs is very important. This is a strongly influenced by the level of quality provided by the company to the consumer which includes product quality and price. The advantage of vaccine products completion can be achieved due to the efficiency of production costs with high quality and competitive prices. In vaccine products it can be done by integrating the making of product innovation in the form of virus content updates based on disease progression in the field, making cocktail composition and price competition.

\section{Development of consumer requirements priority}

The development of consumer requirements priority includes importance level, consumer target value, scale increase factor, point of sale, absolute weight and priority ranking of consumer requirements.

\section{Importance level}

The importance level on the consumer requirements attributes is used to put each consumer's desire with the aim to prioritize the consumer desires. The highest results obtained at the level of importance of consumer requirements are the composition of (4.92), laboratory service (4.17), certification (3.76) expire date (3.72), and price (3.68). Importance level of consumer requirements in Figure 9.

The goal value is the organization goal that wants to achieve, to decide whether to retain, improve, or design new products to outrank its competitors. The goal value is determined based on the evaluation of each customer's requirements from the organization and the competitor and then created a new target value that is equal or exceeds the target value of the competitor.
The result of increase scale factor of each consumer requirement obtains a value from 0.75 to 1.00 which means that it does not need the consumer requirements repair yet it only needs maintenance and development. The increase scale factor below one does not require improvement but the increase scale factor upper one requires improvement.

The sale point is a consumer assessment on each consumer requirements that can provide sales value or affect in increasing sales. High sales value will help and $\mathrm{AI}$ vaccine sale. Consumer requirements that able to help in the AI vaccine sale with (score of 1.5) and then quite helpful enough (score of 1.2) and unhelpful (score of 1) (Table 4).

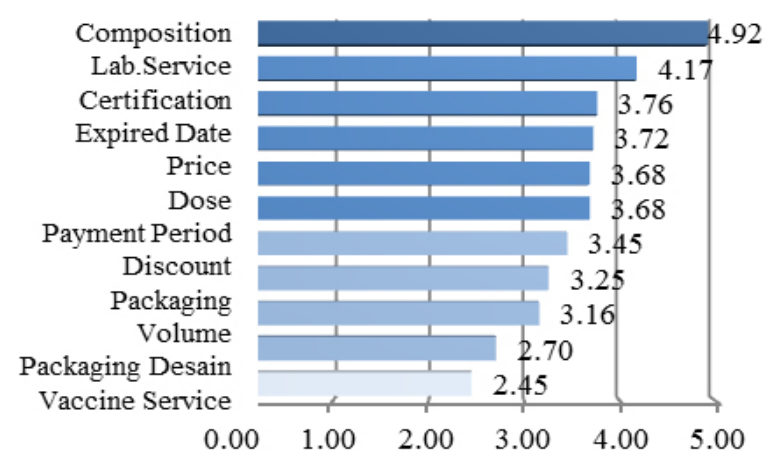

Figure 9. Importance level of consumer requirements

Table 4. Development of consumer requirements priority

\begin{tabular}{cccccc}
\hline $\mathrm{Nu}^{* *}$ & $\begin{array}{c}\text { Goal } \\
\text { Value }\end{array}$ & $\begin{array}{c}\text { Increase } \\
\text { Scale } \\
\text { Factor }\end{array}$ & $\begin{array}{c}\text { Sales } \\
\text { Point }\end{array}$ & $\begin{array}{c}\text { Absolute } \\
\text { Weight }\end{array}$ & $\begin{array}{c}\text { Priority } \\
\text { Rank }\end{array}$ \\
\hline 1 & 3 & 0.75 & 1.2 & 3.33 & 4 \\
2 & 3 & 0.75 & 1.2 & 2.871 & 7 \\
3 & 3 & 0.75 & 1.2 & 3.06 & 5 \\
4 & 3 & 0.75 & 1.5 & 5.70 & 1 \\
5 & 3 & 0.75 & 1.0 & 2.48 & 9 \\
6 & 3 & 0.75 & 1.0 & 2.868 & 8 \\
7 & 3 & 0.75 & 1.0 & 2.03 & 11 \\
8 & 3 & 0.75 & 1.0 & 2.96 & 6 \\
9 & 3 & 1.00 & 1.0 & 2.08 & 10 \\
10 & 3 & 0.75 & 1.2 & 3.91 & 2 \\
11 & 3 & 0.75 & 1.2 & 3.53 & 3 \\
\hline
\end{tabular}

$\left.{ }^{* *}\right)$ No $1-11$ of the consumer requirement sequence 
The absolute weight in consumer requirement describes the consumer requirement priority that needs to be developed by PT ABC. The highest absolute weight rating reflects what consumers expect. If the consumer requirements with the highest attribute value are prioritized to be developed then it will improve the organization performance in accordance with the desire and needs of farmers on developed AI vaccine. The higher the consumer requirement priority ranking the higher the priority level in vaccine development and vice versa.

\section{Development of technical requirements priority}

It is used to evaluate technical requirements that require repair and development to meet consumer requirements. The difficulty degree determines the complexity of technical requirements to be improved and developed in compliance with consumer requirements. Development of $\mathrm{f}$ technical requirements priority in Table 5 .

The highest difficulty value indicates the more difficult the technical requirements to be improved and developed. The objective value of technical requirement is the value that $\mathrm{PT} \mathrm{ABC}$ must acquire to evaluate the structured technical requirements to produce the quality of products in accordance with the consumer expectation.

Absolute weight indicates the priority order of technical requirements that are prioritized for improvement and development.AbsoluteWeightofTechnicalRequirement aims to give the information for PT. ABC to know the efforts to be achieved on technical requirements in the planning and development of produced AI vaccine. Consumer satisfaction fulfillment efforts will be met if all technical requirements are developed, but not all technical requirements are easy to develop because it is constrained by financial and technological capabilities. The first five priority technical requirements are better prioritized because they can represent the improvement with more urgency.

\section{Determination of Technical Requirements Development Direction}

Determining the direction of technical requirements will help PT. ABC to determine whether each technical requirement needs to be upgraded or downgraded. Increasing some technical requirements will result in the quality improvement expected by consumers and vice versa. Technical requirement that can increase profits when lowered is creating a discount strategy to increase sales. It is the smaller the discount the better for the company. This contrasts with the length of post vaccine payments that will increase consumer satisfaction if it targeted within a certain period (longer). Determining the direction of technical requirements development in Table 6.

Table 5. Development of technical requirements priority

\begin{tabular}{cccccc}
\hline $\left.\mathrm{Nu}^{* *}\right)$ & $\begin{array}{c}\text { Difficulty } \\
\text { Degree }\end{array}$ & $\begin{array}{c}\text { Goal } \\
\text { Value }\end{array}$ & $\begin{array}{c}\text { Absolute } \\
\text { Weight }\end{array}$ & $\begin{array}{c}\text { Relative } \\
\text { Weight }\end{array}$ & $\begin{array}{c}\text { Priority } \\
\text { Rank }\end{array}$ \\
\hline 1 & 3 & 4 & 52 & 56 & 5 \\
2 & 2 & 3 & 64 & 48 & 4 \\
3 & 2 & 3 & 28 & 21 & 10 \\
4 & 2 & 3 & 55 & 48 & 6 \\
5 & 2 & 3 & 34.3 & 31 & 8 \\
6 & 3 & 3 & 22 & 22 & 11 \\
7 & 2 & 4 & 38 & 34 & 7 \\
8 & 3 & 3 & 34.2 & 31 & 9 \\
9 & 3 & 3 & 66 & 55 & 3 \\
10 & 3 & 4 & 89 & 88 & 1 \\
11 & 2 & 4 & 75 & 65 & 2 \\
\hline
\end{tabular}

$\left.{ }^{* *}\right)$ No 1-11 of the technical requirement sequence

Table 6. Determining the direction of technical requirements development

\begin{tabular}{cc}
\hline Number & Goal Value \\
\hline 1 & $\mathbf{\Delta}$ \\
2 & $\mathbf{\Delta}$ \\
3 & $\mathbf{\Delta}$ \\
4 & $\mathrm{X}$ \\
5 & $\boldsymbol{\nabla}$ \\
6 & $\mathbf{\Delta}$ \\
7 & $\mathbf{\Delta}$ \\
8 & $\mathbf{\Delta}$ \\
9 & $\mathbf{\Delta}$ \\
10 & $\mathbf{\Delta}$ \\
11 & $\mathbf{\Delta}$ \\
\hline
\end{tabular}

Note: $\boldsymbol{\Delta}$ upgraded, X maintained, $\boldsymbol{\nabla}$ lowered; Meaning of development direction symbol is: symbol $(\boldsymbol{\Delta})$ is given on the technical requirements that will increase consumer satisfaction if it higher or improved, symbol $(\boldsymbol{\nabla})$ is given on the technical requirements that will increase consumer satisfaction if it reduced or lowered, symbol $(\mathrm{X})$ is given to the technical requirements that will increase consumer satisfaction if there is target (range of values) 


\section{QFD Implementation}

QFD analysis result describes the consumer requirement and prioritized technique to be developed according to customer needs and the organization ability to implement it. The strategy formulation of analysis result will help PT. ABC in improving the product quality. The most important consumer requirement is the variable that directly affects the success of vaccine attached to the product.

\section{Composition or quality}

Some of the things to consider in developing the composition/quality of AI vaccines are: 1) The used raw materials must meet the required quality standard; 2) The suitable formulation or composition. Proper formulation will result in a stable and homogeneous form of vaccine. The viral content and type of used viral strain in the vaccine composition will determine the optimal vaccine outcome; 3) Production technology. Vaccine products cannot be separated from the role of sophisticated and cutting-edge technology in its production; 4) Storage temperature. Vaccines are biological products that are vulnerable and easily damaged and highly sensitive to the temperature. The recommended temperature is $2-8^{\circ} \mathrm{C}$, if the temperature does not maintain then it will damage the quality of vaccine, mainly the vaccine potency that becomes less maximal. The vaccine cool chain from manufacturing to the end consumer is becoming the critical point that should be considered; 5) The role of human resources with the competence in veterinary, animal husbandry, pharmaceutical, biology and chemistry related to animal vaccine production will greatly support vaccine production process.

WHO (2018) recommends the composition of the avian influenza vaccine which is in the form of coctail containing trivalent and or quadrivalent with three to four types of viral strains in AI vaccine. This is done to support the quality of the vaccine to be protected from all types of strains challenging AI in the field. Swayne (2009) states that ideally AI vaccines should be capable of a) protection against high field viral challenges, b) long-term protection, usually at least 6-12 months, c) determination of vaccination route such asintramuscular, spray, eye, nose drop, and ovo, d) Minimum number of injected vaccination to achieve protection, ideally once for all types of poultries e) protection against all types of poultry species. Palese (2006) states that the development of a new avian influenza vaccine is good, it needs to fix a critical point on several things: price per dose, speed in production, and ease of production, used virus growth medium, cross protection for variant strain virus, optimal efficacy, safe use, and acceptance of government regulation.

\section{Laboratory Service}

Laboratory services may include blood, organs, feed and water test. The quick respond to the complaints of breeders with laboratory service becomes an important thing needed by farmers. Rapid and accurate test results will greatly help breeders to make decisions in handling chicken health. The evaluation and development of laboratory services those are required for improvement is the completeness of testing, system testing, alertness and speed in providing test results as well as conclusion and recommendation of test results. Indovax (2007) states that laboratory testing, mainly chicken serology testing is very important and has a huge advantage for breeders, namely: a) determining the age of vaccination, b) evaluating and improving vaccination program, c) routine serologic examination of each cage, d) serologically diagnosis, e) disease surveillance program.

\section{Certification}

Certifications obtained from government and independent agencies also become one factor that is considered by the consumer. Poultry vaccine companies that have national and international certification will provide a confidence to consumers on the produced vaccine quality. The obtained certification illustrates the quality assurance of produced vaccine quality. Supriono (2017) states that in facing the global competition, the product quality by the company that needs to be considered because consumer awareness about product quality is increasing nowadays. Product quality assurance is obtained from national and international certificate. Therefore, the company needs to get recognition stating that the used products and systems are suitable with the standards. The required national standards are Good Manufacturing Practice (GMP) certification while the commonly used of international standard of quality management is ISO 9001: 2015. 
Price

Vaccine prices are also a consideration for breeders to buy AI vaccine, although it is not the priority. The population of laying hens with large numbers tends to concern on an affordable price with the appropriate quality.

\section{Managerial Implications}

Managerial implications based on research results that can be recommended for fulfill the needs and desires of laying hens is to focus on development, improvement, and planning to the priority variables that are important in designing AI vaccine products are: a) Product innovation is very important thing to plan and do. Innovation is the key to AI vaccine products can compete and be accepted by consumers; b) Development of vaccine composition by implementing a strategy for developing multivalent AI vaccines; c) Evaluation and development of laboratory services such as complete testing, testing systems, readiness and speed in providing test results as well conclusions and recommendations for testing results because this is very helpful in diagnosing disease and monitoring chicken health; d) Planning for registration of international certification will increase consumer confidence in the quality assurance of AI vaccines produced; e) Evaluating and setting competitive prices will increase competitiveness with similar competitor companies. Supervision and control of the process of implementation, development, improvement and planning of the important variables continues to be carried out and evaluated.

\section{CONCLUSIONS AND RECOMMENDATIONS}

\section{Conclusions}

The strategy that can be performed by the producers to meet the breeders needs and desire based on the results of QFD analysis is a) the development of consumer requirements that is composition, laboratory service, certification and price $b$ ) the development of prioritized technical requirements is to make a coctail composition, set competitive price, viral content based on the disease progress in the field.

\section{Recommendations}

Performing the improvement and development of consumer priority variable that is composition, certification laboratory service and price. The subsequent research is using QDF analysis by adding cost variables if perform the development variable that mostly needed by the breeders so that it will provide more comprehensive information.

\section{REFERENCES}

[BPS] Central Bureau of Statistics. 2017. Number of Households of Livestock Business According to Region and Type of Livestock in West Java Province. https://st2013.bps.go.id/dev2/index. $\mathrm{php} /$ site $/$ tabel?tid $=50 \&$ wid $=3200000000$. [June 03, 2017]

[Secretary General of the Ministry of Health] 2015. The 198th and 199th Special Reports about Avian Influenza. Ministry of Health Republic of Indonesia. http://www.depkes.go.id/article/ view/15040100002/laporan-kasus-flu-burungke-198-dan-199.html. [05 Juni 2017]

[WHO] World Health Organization. 2013. What Influences Vaccine Acceptance: A Model of Determinants of Vaccine Hesitancy. http://www.who.int/immunization/sage/ meetings/2013/april/1_Model_analyze driversofvaccineConfidence_22_March.pdf. [14 april 2017 14].

[WHO]WorldHealthOrganization.2018.Recommended Composition of Influenza Virus Vaccines for use in the 2018- 2019 Northern Hemisphere Influenza Season. http://www.who.int/influenza/ vaccines/virus/recommendations/201802 recommendation.pdf. [5 Juni 2018].

Azhar M. 2016. Current AI Disease Situation and Commercial Poultry Health Services. National Poultry Breeders Seminar - 2016 Indolivestock. Department of Agriculture.

Basuno E. 2008. Review of the Epidemic Impact and Avian Influenza Control Policy in Indonesia. Agricultural Policy Analysis. 6:314-334 No 04 2008. pse.litbang.pertanian.go.id/ind/pdffiles/ ART6-4b.pdf. [June 3, 2017].

Diyantoro, Pribadi ES. 2017. Analysis of mycoplasma gallisepticum infection factors in commercial layer chicken farm using analytical hierarchy process. Journal of Vocational Health Studies 
1(2):44-49.http://dx.doi.org/10.20473/jvhs. V1.I2.2017.44-49

Ilham N. 2014. Spreading of avian flu on duck and its impact on social economy: lesson learnt from avian flu cases on chicken. WARTAZOA 23(2):84-93.http://dx.doi.org/10.14334/ wartazoa.v23i2.718.

Nofifta D. 2015. Keuntungan dan kerugian penggunaan vaksin avian influenza pada unggas [skripsi]. Bogor: Institut Pertanian Bogor.

North MO. 1984. Commercial Chicken Production Manual. Poultry Management Consultant Aceanside, California. USA: Avi Publishing Company.

Nurliza, Dolorosa E. 2017. Quality Dimensions of Purchase Behavior Decision on Fishery Products. Jurnal Manajemen \& Agribisnis 14(2):79-81.

Palese P. 2006. Making better influenza virus vaccines. emerging infectious diseases. Emerging Infectious Diseases 12(1): 61-65.

Parede L. 2006. Local Vaccine Development Strategy in Controlling and Preventing Disease on Free-Range Chickens. National Workshop on Technology Innovation of Free-Range Chicken Development. Bogor: Veterinary Research Center.

Putri DD. 2012. Appropriate avian influenza vaccination time (AI) to produce protective immunologic response on broiler race chickens. Journal of Applied Agricultural Research 12 (3): 150-155.

Radji M. 2006. Avian influenza a (H5N1): pathogenesis, prevention and spreading in humans. Pharmaceutical Science Magazine 3(2):55-65.

Ratnawati S, Hau DK, Nulik J, Handriwirawan E. 2010. Improved Maintenance Management in supporting the development of local poultry in East Nusa Tenggara. National Workshop on Technology Innovation Development of local chickens. Bogor: Center for livestock research and development.

Smith GJ et al. 2006. Evolution and adaptation of $\mathrm{H} 5 \mathrm{~N} 1$ influenza virus in avian and humanhosts in Indonesia and Vietnam. Virology 350(2): 258268. https://doi.org/10.1016/j.virol.2006.03.048.

Songserm T et al. 2006. Domestic ducks and H5N1 influenza epidemic, Thailand. Emerging Infectious Diseases 12(4):575-81.

Suprapti SBW, Nuraeni S. 2009. The effect of market share, laverage ratio, and capital intensity ratio on stock return. Karisma 3(2): 139-146.

Supriono FFR. 2017. Implementation analysis of quality management system of ISO 9001: 2015 in supporting marketing. Journal Business Administration (JAB) 53(1).

Suwito W, Supriadi, Primatika RA, Winarti E. 2013. Avian Influenza (AI) vaccine study on free-range chicken with brackets cage system at Gunung Kidul Yogyakarta. Livestock Science 11(1).

Swayne DE. 2009. Avian influenza vaccines and therapies for poultry. Comparative Immunology, Microbiology and Infectious Diseases 32 (2009) 351-363. https://doi.org/10.1016/j. cimid.2008.01.006.

Tabbu CR. 2000. Chicken Disease and its Prevention: Bacterial, Mikal and Viral Disease. Yogyakarta: Kanisius Publisher.

Wong SF et al. 2014. A protocol for a discrete choice experiment:understanding preferences of patients with cancer towards their cancer care across metropolitan and rural regions in Australia. $B M J$ Open 4(10). https://doi.org/10.1136/bmjopen2014-006661.

Zenal FC. 2017. Surveillance of Poultry Market Environment 2009-2016 and Its Development. National Technical Advisor for Surveillance FAO ECTAD Indonesia. 